\title{
The Impact of Nitrogen Pollution in the Agricultural Landscape on Lichens: A Review of Their Responses at the Community, Species, Biont and Physiological Levels
}

\author{
Daria Zarabska-Bożejewicz
}

Institute for Agricultural and Forest Environment, Polish Academy of Sciences, Bukowska 19, 60-809 Poznań, Poland; zardaria@wp.pl

Received: 3 October 2020; Accepted: 22 November 2020; Published: 25 November 2020

\begin{abstract}
Lichenized fungi are widely used as bioindicators owing to their sensitivity to various anthropogenic impacts. Increased nitrogen deposition affects the occurrence, abundance and distribution of lichens. The main sources of nitrogen in the agricultural landscape are ammonia $\left(\mathrm{NH}_{3}\right)$ and the ammonium cation $\left(\mathrm{NH}_{4}{ }^{+}\right)$. Livestock farming and the use of organic and mineral fertilizers are primarily responsible for the emissions of these compounds. $\mathrm{N}$ in excess can negatively impact lichen biota and lead, for example, to species decline, impoverishment of lichen communities or unbalanced symbiosis. However, there is also evidence for certain opposite effects, in particular at medium $\mathrm{N}$ concentrations. Positive influences may be manifested, for example, by higher chlorophyll a concentrations, or by a greater lichen diversity being supported by the coexistence of lichens with different trophic requirements. Indicator values of lichens in relation to $\mathrm{N}$ input are exhibited, for example, by some biont markers (the contents of ergosterol and chlorophyll a), particular species, such as Xanthoria parietina, or trophic functional groups (oligotrophilous and nitrophilous lichens). Gaps identified in the current knowledge are discussed.
\end{abstract}

Keywords: lichenized fungi; elevated nitrogen deposition; bioindication

\section{Nitrogen Pollution in the Agricultural Landscape}

Nitrogen deposition has been increasing in recent decades, and this process appears to be unstoppable, at least in the near future [1-3]. This trend is related to continuing human population growth and accompanying human needs, such as food and energy production. Galloway et al. [4] reported a 10-fold increase in reactive nitrogen (Nr) formation due to human activities and a 15\% decrease in the natural terrestrial production of $\mathrm{N}$ from 1860 to the early 1990s. According to Engardt et al. [3], the annual deposition of reduced nitrogen in Europe in 1900 was less than half the present figure. Three-quarters of anthropogenic $\mathrm{Nr}$ are applied to agroecosystems [4].

The main sources of nitrogen in the agricultural landscape are ammonia $\left(\mathrm{NH}_{3}\right)$ and the ammonium cation $\left(\mathrm{NH}_{4}{ }^{+}\right)$. Agricultural activities, principally livestock farming, the application of organic and mineral fertilizers, and biomass burning, contribute significantly to emissions of these compounds [5-12]. The mineralization of organic $\mathrm{N}$-containing amino acids and urea during the aerobic treatment of organic waste (composting) is a further source of $\mathrm{NH}_{3}$ [13]. In Europe, $\sim 90 \%$ of the total $\mathrm{NH}_{3}$ emission from agriculture is lost to the air [14]. The deposition rate of this $\mathrm{NH}_{3}$ is rapid, so that most is distributed close to the emission source [5]. Van Herk et al. [15] pointed out that ca $10 \%$ of $\mathrm{NH}_{3}$ can be found within $100 \mathrm{~m}$ downwind, but the unaltered compound can reach only $50 \mathrm{~km}$ downwind. However, much of the $\mathrm{NH}_{3}$ can ionize to $\mathrm{NH}_{4}{ }^{+}$when dissolved in water, and then it can be transported as far as $1000 \mathrm{~km}$ ([15] and the literature cited therein). 
Ammonia deposition significantly increases bark $\mathrm{pH}$, thus contributing to its eutrophication $[8,16]$. In contrast, nitrification converts $\mathrm{NH}_{4}{ }^{+}$into the nitrate ion $\left(\mathrm{NO}_{3}{ }^{-}\right)$, resulting in substrate acidification [15]. Nitrate levels and the intensity of agricultural inputs were found to be positively correlated; the highest value being found within built-up rural areas [16]. In the atmosphere, ammonia can react with acid oxides to form salts, e.g., ammonium sulphate $\left[\left(\mathrm{NH}_{4}\right)_{2} \mathrm{SO}_{4}\right]$ [16]. Being responsible for the increasing availability of nitrogen, $\mathrm{NH}_{4}{ }^{+}$is mainly deposited in the form of $\left(\mathrm{NH}_{4}\right)_{2} \mathrm{SO}_{4}[8,16]$. Most of the $\mathrm{NH}_{3}$ accumulated in the soil is converted into nitric acid $\left(\mathrm{HNO}_{3}\right)$ during nitrification [8].

Nitrogen oxides $\mathrm{NO}_{X}$ are further important, deposited atmospheric nitrogen compounds [12]. These reactive gases are derived from natural and anthropogenic sources, the main ones being road vehicle exhausts and industrial processes based on high-temperature combustion [3,5,12,16-19]. In contrast to $\mathrm{NH}_{3}$, nitrogen oxides are only slowly deposited but can be transported over considerable distances $[5,19]$.

The nitrogen $(\mathrm{N})$ supply to terrestrial ecosystems can lead, for example, to nutrient imbalances in leaf tissues, changes in plant communities and soil acidification ([20] and the literature cited therein). The acidification and eutrophication due to elevated $\mathrm{Nr}$ concentrations negatively influence ecosystem biodiversity [4]. In particular, plant species adapted to low nutrient availability are disappearing, being displaced by ubiquitous, fast-growing species that tolerate nutrient-richer habitats [21].

Lichenized fungi are widely used as bioindicators, since they are sensitive to various anthropogenic impacts, including atmospheric pollution, forest management, land use and climate change. Their sensitivity is related to their biology; lacking protective tissues, lichens can absorb water, nutritive substances and gases directly from the atmosphere [17]. The response of lichens to nitrogen deposition is, firstly, related to direct toxicity from $\mathrm{Nr}$ gases and aerosols, and secondly, to changes in species interactions [20].

The literature provides much information about the impact of elevated $\mathrm{N}$ deposition on lichens at the physiological, biont, species and community levels; the present article reviews these papers. The importance of this topic is likely to rise, especially in view of the expected global increase in nitrogen deposition, which could become a major threat to a great many lichen species, including red-listed ones $[1,2,22]$.

A number of electronic databases, i.e., Google Scholar, PubMed, Science Direct and Springer, were gleaned for studies that contained the following combinations of words: "lichens \& elevated nitrogen input", "lichens \& nitrogen deposition", "lichens \& fertilizations", "lichens \& agricultural landscape". Additional studies obtained from the references cited in the articles from the initial search were also consulted. The last search was carried out on 4 September 2020. This review covers 84 papers, dating from 1958 to 2020.

\section{Detection of N Impact on Lichens: Importance of Environmental Datasets}

Although $\mathrm{N}$ is an essential nutrient required by both bionts forming the lichen thallus, greater quantities can have a negative impact. According to some authors, the rise in bark $\mathrm{pH}$ associated with $\mathrm{NH}_{3}$ adsorption seems to be more important for the occurrence of lichens than elevated bark $\mathrm{NH}_{4}{ }^{+}[8,23]$. A lichenological survey carried out around a pig stockfarm in central Italy demonstrated a positive correlation between bark $\mathrm{pH}$ and $\mathrm{NH}_{3}$ concentration; $\mathrm{pH}$ fell with increasing distance from the ammonia emission source [23]. Moreover, this study found no correlation between bark $\mathrm{NH}_{4}{ }^{+}$and parameters such as atmospheric $\mathrm{NH}_{3}$, the total lichen diversity or the diversity of strictly nitrophilous species [23]. In a cork-oak Mediterranean woodland growing in the vicinity of a cattle farm, the very high variability ( $\sim 90 \%)$ in the distribution of lichens was explained by the atmospheric $\mathrm{NH}_{3}$ concentration [24]. With increasing $\mathrm{N}$ concentration, however, $\mathrm{NH}_{4}{ }^{+}$was found to be preferred over nitrate by some Usnea and Ramalina lichens [25]. The lower energy demands of other species are known to be due to their uptake of $\mathrm{NH}_{4}{ }^{+}$in preference to nitrate ([25] and the literature cited therein). On the other hand, Jovan et al. [26] recognized multiple forms of $\mathrm{N}$ instead of $\mathrm{NH}_{3}$ and the $\mathrm{pH}$ of the tree substrate as important factors determining the response of nitrophilous lichens. This is consistent with the result 
demonstrating that lichen functional groups with different nitrogen tolerances varied under the impact of the main gaseous pollutants, including $\mathrm{NH}_{3}$ and $\mathrm{NO}_{X}$ [27]. In addition, no significant correlation between bark $\mathrm{pH}$ and the composition of epiphytic lichen communities exposed to excessive amounts of nutrients was demonstrated [27]. Hogan et al. [28], too, found that the form of $\mathrm{N}$ to which Cladonia portentosa (Dufour) Coem. was exposed was unimportant, but did find differences in the $\mathrm{N}$ thallus concentration, N:P mass ratio and phosphomonoesterase (PME) activity due to nitrogen enrichment. Johansson et al. [29] conducted experimental studies in a boreal spruce forest on the response of the more N-sensitive Alectoria sarmentosa (Ach.) Ach. and the less N-sensitive Platismatia glauca (L.) W.L. Culb. \& C.F. Culb. to increased atmospheric nitrogen $(\mathrm{N})$ deposition. Nitrogen was applied as $\mathrm{NH}_{4} \mathrm{NO}_{3}$ fertilizer in loads ranging from 0.6 to $50 \mathrm{~kg} \mathrm{~N} \mathrm{ha}{ }^{-1} \mathrm{yr}^{-1}$ : the uptake of $\mathrm{NH}_{4}{ }^{+}$and $\mathrm{NO}_{3}{ }^{-}$of both species was similar [29]. In the nearest future studies, it could be interesting to provide new evidences confirming the role of multiply forms of nitrogen on the occurrence of lichens. Moreover, it is still unclear if the effect of elevated $\mathrm{N}$ deposition varies in relation to the share of different nitrogen forms. More studies are also needed to recognize which lichen indices (e.g., functional groups, particular species, physiological reaction) allow for better investigations of the impact of particular or multiply forms of nitrogen.

It should be borne in mind that environmental and substrate-related factors can independently or jointly affect the occurrence of lichens, their growth and elemental uptake (e.g., [23,27,30,31]). Therefore, the direct impact of elevated nitrogen deposition on lichen biota may be more difficult to detect. According to Bruteig [30], environmental data should complement deposition analyses.

Several studies have identified dust as a factor that can mask the effect of $\mathrm{NH}_{3}$. Impregnation with calcareous dust can cause a rise in bark $\mathrm{pH}$, for instance, in Mediterranean areas with a warm and dry climate $[6,23,32,33]$. Under such circumstances, phorophytes like oaks, which normally have an acid bark, promote the establishment and presence of lichens preferring a higher substrate $\mathrm{pH}$. Moreover, dust-impregnated bark is drier, favouring the occurrence of xerophilous lichens. Nitrophilous lichens are presumed to be drought-resistant, and this property can be related to the higher cell-liquid conductivity of nitrophilous lichens compared to species adapted to non-nitrophilous conditions [11]. Open areas are generally drier than, say, forest sites, which may partially explain the abundance of nitrophilous, often also xerophilous, lichens in the agricultural landscape [6,33]. Air pollution appears to have an especially marked effect on lichens at sites with lower air moisture levels. This statement is corroborated by reports that rainwater solutions containing high levels of $\mathrm{N}$ compounds, deposited in greater amounts on lichen thalli during dry weather, are more detrimental to the lichen community composition than solutions that are more dilute because these compounds are more often washed off by rain in wetter areas [34]. Comparisons of the nitrophilous lichen responses between habitats located in open areas but under different levels of $\mathrm{N}$ enrichment, for example based on the determination of land use intensity, could allow for better explanation in which extend local climatic conditions influence this response. Hogan et al. [28] pointed out that the effects of nitrogen on lichens are likely to be confounded by rainfall depth; their investigation of relationships between the physiology of Cladonia portentosa and nitrogen enrichment showed that $\mathrm{N}$ deposition was positively associated with rainfall depth [28]. Similar patterns of chlorophyll a and ergosterol variation in Xanthoria parietina (L.) Th. Fr. exposed to the two lowest $\mathrm{NH}_{4} \mathrm{Cl}$ concentrations $(0.04$ and $0.17 \mathrm{M})$ compared with the control materials could be primarily explained by seasonal variation in rainfall and therefore subsequent lichen activity periods [31]. In contrast, positive correlations between growing degree-days and altitude with the nitrogen content in lichen thalli were found in Hypogymnia physodes (L.) Nyl. [30]. In addition, the relatively high total nitrogen content found in thalli of this epiphyte was partially linked with unfavourable growth conditions at some inland collection sites, i.e., long, cold winters and low summer precipitation [30]. In a meta-analysis of the literature Gutiérrez-Larruga et al. [35] reported the highest impact of $\mathrm{N}$ on the abundance and metabolism of chlorolichens from regions with high precipitation $(>1000 \mathrm{~mm})$ and with a background $\mathrm{N}$ deposition of mixed agricultural and industrial origin. They also found that the $\mathrm{N}$ supply in particular affected lichens from environments offering conditions that promote their growth and activity [35]. It still remain unknown, how climatic conditions 
(i.e., precipitation, aridity) influence the response of the lichen biota to $\mathrm{N}$ enrichment. More studies conducted both in regions with more and less favourable conditions for lichens persistence under elevated $\mathrm{N}$ deposition could verified observations presented above.

The response of lichens to light conditions may be a factor of no little importance; moreover, nitrophilous lichens are better adapted to sites more exposed to the sun. Hauck and Wirth [36] reported a correlation between shade adaptation and sensitivity to nitrogen pollution in epiphytic and saxicolous lichens. If light is limiting, the photosynthetic production of the $\mathrm{C}$ skeletons needed for $\mathrm{N}$ assimilation may be restricted [36]. The $\mathrm{N}$ content in lichen thalli may also depend on their exposure and the characteristics of adjacent collection sites. For example, the stronger exposure of Xanthoria parietina to wind and therefore the impact of larger doses of nitrogen might explain, at least partially, the higher nitrogen concentration in thalli of this species collected from roof tiles compared to other examined lichens growing on sheltered tree trunk [37]. In addition, the similar exposure of Xanthoria parietina at collection sites on roof tiles substantially minimized the possible influence of irradiance levels on the chlorophyll a content in relation to thallus $\mathrm{N}$ concentrations [38]. The extent of exposure of lichen thalli, as well as precipitation and the nitrogen concentration in the air, can influence the dose of nitrogen received by thalli [5].

Giordani and Malaspina [27] investigated the influence of bark $\mathrm{pH}$, trunk circumference and light on lichen functional groups, classified according to their trophic requirements. Both the total amount of through-canopy solar radiation and bark $\mathrm{pH}$ were excluded from the group of statistically significant predictors that could explain the diversity of lichen functional groups [27]. In contrast, trunk circumference influenced their abundance [27], a finding related to changes in atmospheric pollutant levels. At high levels of atmospheric nitrogen emissions, trees of different ages support consecutive colonizations by highly tolerant nitrophilous species [27]. According to Wolseley et al. [19,39] the lichen biota occupying younger substrates, such as twigs, are likely to reflect current conditions concerning atmospheric ammonia concentrations. Some variations in elemental uptake may be related to other factors that are difficult to control, such as canopy leakage and the age of individual lichen thalli [30]. It is also worth noting that not only the effect of environmental variables but also the lichen traits, for example growth form, substratum specialization, reproductive strategy or photobiont type, may determine the presence of species. Stofer et al. [40] investigated the impact of land use on lichen biota based on certain functional traits and demonstrated that more fertile species, lichens with Trebouxia s.l. as the principal photobiont, as well as generalists as regards substratum specialization, i.e., species growing on more than three substrata, were found in open farmland areas, with a significant decrease in lichen species richness compared to a landscape where agricultural management is less intensive.

Since many factors can determine the establishment and maintenance of particular lichen species only experiments in controlled laboratory conditions seem to allow for more reliable characteristics of the direct impact of $\mathrm{N}$ supply on the lichen biota. Some field studies can minimalize the risk of explanations of lichen persistence under co-occurrence of multiply factors if investigations of lichen transplants reaction are considered. However, it is necessary to make an effort to collect lichens from younger substrates based on the assumption of more similar age of individuals growing on younger than on older substrates. Moreover, transplants should be exposed in similar habitat and climatic conditions with known background level of $\mathrm{N}$ deposition.

\section{Physiological and Biont Responses of Lichens to Nitrogen Input}

Lichens, or lichen-forming fungi or lichenized fungi, are defined as a stable and self-supporting association of a mycobiont and a photobiont [41]. The fungal component is the external partner and the classification of lichens depends on its taxonomy. The photobiont partners are algae or cyanobacteria. Since at least two organisms participate in forming the lichen symbiosis, the responses of the respective bionts to increased nitrogen $(\mathrm{N})$ emissions and concurrent $\mathrm{N}$ deposition should be identified. Early signs of injury at the biont level usually precede harmful changes within lichen communities in N-impacted environments (e.g., [9,42]). Gutiérrez-Larruga et al. [35] showed that under excessive N-deposition, 
the lichen metabolism alters in the short term before decreasing lichen abundance can be detected in the medium to long term.

The $\mathrm{N}$ content in lichen thalli is affected by nitrogen emissions: both organic and inorganic forms of $\mathrm{N}$ are present in them [37]. Inorganic contaminants can be found in lichenized fungi: (1) on the surfaces of lichen thalli or in intercellular spaces (as particles), (2) bound as ions to the surface (on the extra- or intracellular exchange side), and (3) within cells (as ions) [43]. Many studies showed clear positive correlations between $\mathrm{N}$ concentrations in lichen thalli and $\mathrm{N}$ supply. In Physcia caesia (Hoffm.) Furnrohr, a positive correlation between $\mathrm{N}$ deposition and the total $\mathrm{N}$ content of thalli near emission sources was detected [7]. Frati et al. [23] found that concentrations of accumulated $\mathrm{N}$ in the thalli of the nitrophilous species Xanthoria parietina and the non-nitrophilous lichen species Flavoparmelia caperata (L.) Hale were negatively correlated with distance from a pig stockfarm, whereas the relationships with atmospheric $\mathrm{NH}_{3}$ concentrations were positive. Similarly, an elevated $\mathrm{N}$ load resulted in an increase in thallus $\mathrm{N}$ concentration in the more $\mathrm{N}$-sensitive Alectoria sarmentosa and the less N-sensitive Platismatia glauca [29]. Higher N concentrations from $1.1 \%$ DW to $1.37 \%$ DW were detected in the nitrophilous Xanthoria parietina (2.53\% DW), compared to some non-nitrophilous species (Ramalina fastigiata (Pers.) Ach., Flavoparmelia caperata, Evernia prunastri (L.) Ach.) collected at the same site [37].

The response to nitrogen stress may be associated with polyamines. It has been reported that the sensitivity of Evernia prunastri and the tolerance of Xanthoria parietina to nitrogen stress were reduced as a result of an external supply of polyamines and polyamine inhibitors, respectively [44]. Under controlled experimental conditions, Hogan et al. [28] examined the impact of nitrogen and phosphorus enrichment on phosphomonoesterase activity in Cladonia portentosa. Regardless of the $\mathrm{N}$ form, the $\mathrm{N}$ thallus concentration, N:P mass ratio and phosphomonoesterase (PME) activity were increased, whereas P-limitation was induced by the $\mathrm{N}$ supply. Johansson et al. [29] conducted experimental studies in a boreal spruce forest on the response of Alectoria sarmentosa and Platismatia glauca to increased atmospheric nitrogen $(\mathrm{N})$ deposition. A lower concentration of phosphorus $(\mathrm{P})$ in the more $\mathrm{N}$-sensitive Alectoria sarmentosa and an increase in the N:P ratio in both species were detected as an effect of this nitrogen supply [29]. It was also found that the morphology and function of the lichen thallus can impact the level of $\mathrm{N}$ uptake in the algal cells compared with the fungal tissue [29]. The loosely packed algal layer supports air circulation and reduces resistance to $\mathrm{CO}_{2}$ diffusion (Honnegger, 1991: in [29]), and also prevents self-shading (Valladares et al., 1996: in [29]). Lichens can accelerate their growth to avoid the negative influence of excess N. However, in such a situation, elements other than nitrogen, like phosphorus, may be factors limiting lichen growth. The filamentous Alectoria sarmentosa was more sensitive to elevated $\mathrm{N}$ loads than the foliose Platismatia glauca because of the morphological constraints in its thalli that limit the photobiont concentration [29].

Lichens cope with nitrogen enrichment by their ability to produce sufficient numbers of $\mathrm{C}$ skeletons that permit the rapid conversion of $\mathrm{NH}_{4}{ }^{+}$to amino acids, thus preventing a build-up of $\mathrm{NH}_{4}{ }^{+}$to toxic levels $[1,20]$. This ability may be lost as a result of pigment acidification caused by increased $\mathrm{N}$ deposition, which induces conversion of chlorophyll to phaeophytin (non-photosynthetic) pigments [20]. The cation exchange capacity of lichens can, at least partially, explain their response to nitrogen input [38]. A low cation exchange capacity restricts the possibility of nitrogen to becoming bound to cell walls, thereby enhancing the resistance of lichens species to the harmful effect of elevated nitrogen [37]. A lower cation exchange capacity for nitrogen was found in Xanthoria parietina than in Flavoparmelia caperata; both species differ in their nutrient requirements [37]. This feature determines the tolerance of Xanthoria parietina to N supplied in excess [37,38]. In contrast, other species, e.g., Evernia prunastri, sensitive to nitrogen input, were found to have a higher cation exchange capacity [37]. Determinations of cation exchange capacity could support the protection of lichens by specification of threats for sensitive lichens in relation to $\mathrm{N}$ supply.

Exposure to elevated $\mathrm{N}$ can have a harmful effect on both bionts in the lichen thalli, as exhibited by the decreasing contents of chlorophyll a and ergosterol, especially in non-nitrophilous lichens [31]. 
On the physiological level, excess $\mathrm{N}$ directly affects the integrity of fungal cell membranes, chlorophyll and the function of photosystem II (PSII) in photobionts, among other things ([25] and the literature cited therein). In addition, carbon and associated symbiotic balances between components of lichen thalli may change under the impact of $\mathrm{N}$ [25].

To date, numerous studies have examined the physiological responses of lichen bionts to excess nitrogen. Some of them demonstrated a positive correlation between physiological factors characteristic of photobionts and the presence of excess $\mathrm{N}$ (at least at lower concentrations) in the environment. For example, the chlorophyll a concentration in Xanthoria aureola (Ach.) Erichsen was found to be elevated following experimental spraying experiment with $\mathrm{NH}_{4} \mathrm{NO}_{3}$ [22]. A greater increase in chlorophyll a concentration compared with the ergosterol content accompanied an increase of thallus $\mathrm{N}$ in Xanthoria parietina [38]. Because of the increased metabolic cost of $\mathrm{N}$ assimilation, the autotrophic component in lichen thalli may exhibit photosynthetic adjustment responses [38]. Palmqvist and Dahlman [45] examined the response of Platismatia glauca to altered resource supply by manipulating nitrogen $(\mathrm{N})$ availability and light exposure. The chlorophyll a concentration increased following a rise in thallus $\mathrm{N}$ concentrations, whereas the mycobiont ergosterol concentration remained stable [45]. Experimental studies in a boreal spruce forest revealed a linear increase of the photobiont concentration in the more $\mathrm{N}$-sensitive Alectoria sarmentosa and the less N-sensitive Platismatia glauca as a result of increased N inputs. By the third year of the experiment, however, the thallus of Alectoria sarmentosa was saturated with photobiont cells at the level of $\mathrm{N}$ inputs of 25 and $50 \mathrm{~kg} \mathrm{ha}^{-1} \mathrm{yr}^{-1}$ [29].

Maslaňáková et al. [12] found that the photosynthetic parameters in Cladonia arbuscula ssp. mitis (Sandst.) Ruoss, were unaffected by higher nitrogen concentrations. In contrast, Wang et al. [25] reported that despite an initial increase the photobiont responded negatively to excessive $\mathrm{N}$ deposition. In another experiment, Gaio-Oliveira et al. [31] reported that thalli of Xanthoria parietina exposed weekly over a 10-month period to two higher $\mathrm{NH}_{4} \mathrm{Cl}$ concentrations $(0.34$ and $0.69 \mathrm{M})$ exhibited reduced chlorophyll a and ergosterol concentrations. Paoli et al. [9] examined the photosynthetic performance of lichens using transplants of Evernia prunastri and Pseudevernia furfuracea (L.) Zopf impacted by atmospheric $\mathrm{NH}_{3}$ pollution. Those authors demonstrated the sensitivity of photosystem II to this N pollutant; a marked decrease in the potential quantum yield of PSII was detected in thalli exposed near a sheep farm [9]. The sensitivity of the photobiont in Flavoparmelia caperata to N pollution was manifested by chlorophyll degradation and diminished photosynthetic performance, whereas in Xanthoria parietina, only the highest concentration affected the autotroph [10]. Under the impact of ammonium nitrate $\left(\mathrm{NH}_{4} \mathrm{NO}_{3}\right)$, the photobiont of Cladonia arbuscula ssp. mitis was found to be less sensitive to higher nitrogen concentrations than the autotrophic component in Cladonia furcata (Huds.) Schrad. [12]. Nitrogen fertilization probably lowered the content of photosynthetic pigments (chorophyll a, b and carotenoids) in Evernia prunastri [18]. The sensitivity of this lichen species and Xanthoria parietina to nitrogen stress were examined under laboratory conditions: although nitrate was found to have no effect on Evernia prunastri, the photosynthetic efficiency of this species was altered by the high ammonium concentration, regardless of the light regime [44]. However, Evernia prunastri displayed a reduced sensitivity to nitrogen stress as a result of the external supply of polyamines [44]. In another study, responses to ammonia emissions from the industrial composting of organic waste were different for both these species: proximity to the facility had no effect on Xanthoria parietina [42]. Moreover, the photosynthetic performance of lichen samples at the composting facility and $200 \mathrm{~m}$ from it was superior to that of samples transplanted to a distance of $400 \mathrm{~m}$ away from it [42]. In Evernia prunastri, however, photosynthetic performance, cell membrane integrity and dark respiration were all altered following exposure at the composting facility [42]. The physiological response of both species was investigated in relation to short-term $\mathrm{NH}_{3}$ exposure [46]. Photosystem II in Evernia prunastri was found to be highly sensitive to the $\mathrm{NH}_{3}$ concentration; the subsequent change in photosynthetic performance in this species was responsible for its absence in Nr-rich habitats [46]. In this lichen species, a decrease in $\mathrm{Fv} / \mathrm{Fm}$ was detected at $>3 \mu \mathrm{g} / \mathrm{m}^{3} \mathrm{NH}_{3}$, whereas in Xanthoria parietina a similar result in relation to the capacity of photosystem II was found at $>50 \mu \mathrm{g} / \mathrm{m}^{3} \mathrm{NH}_{3}$ [46]. 
Based on the results presented above it could be stated that lichen photobionts are positively simulated under low and medium levels of nitrogen supply. These levels seem to be dependent from species investigated, being lower in more sensitive and higher in N-resistant lichens. Moreover, it can be one of the reason why relatively rich lichen biota, including oligotrophic species, is able to persist in areas with low traditional farming obviously characterized by lower output of $\mathrm{N}$.

Ergosterol, an important sterol in fungal cell membranes, is also sometimes found in algae [47]. Analyses of cell membrane integrity, in particular in relation to a mycobiont, can be used to detect early signs of lichen damage under nitrogen stress [48]. Ergosterol is known to be a marker for the fungal component [49], although its concentration may reflect the amounts of metabolically active cells in both bionts [47]. According to Munzi et al. [48], the fungal partner is more affected by nitrogen stress than the autotroph biont. Maslaňáková et al. [12] also confirmed that it is the fungal partner in lichen thalli that governs the sensitivity of lichens to excess nitrogen. The greater sensitivity of the mycobiont than the photobiont to fertilization was evidenced by lower losses of chlorophyll a than ergosterol when exposed to $0.34 \mathrm{M} \mathrm{NH}_{4} \mathrm{Cl}$ [31]. Differences in the response of Cladonia arbuscula ssp. mitis and Cladonia furcata to ammonium nitrate $\left(\mathrm{NH}_{4} \mathrm{NO}_{3}\right)$ were attributed to the greater sensitivity of the mycobiont in the former species to nitrogen stress [12]. Ergosterol reduction, membrane lipid peroxidation and conversion of secondary metabolites were detected in Flavoparmelia caperata under the impact of nitrogen pollution [10]. On the other hand, Gaio-Oliveira et al. [38] examined ergosterol in relation to thallus $\mathrm{N}$ concentrations: a positive, statistically significant correlation, though weak, was found between these two parameters. Similarly, Wang et al. [25] failed to discover any pronounced effect of excessive $\mathrm{N}$ deposition on lichen mycobionts: in contrast to the lichenized algal cells, the growth of the fungal component was not $\mathrm{N}$ limited [50]. Better insight into direct effect of $\mathrm{N}$ supply on the mycobiont could give some comparisons between concentrations of chitin and ergosterol. Chitin can be used as marker of fungal biomass. A significant positive impact of $\mathrm{N}$ on the thallus growth is well recognized (see Section 4: Growth of Lichens vs. Nitrogen Input). Since most of the lichens biomass is comprised by the mycobiont, it could be interesting to recognize, if there are any correlations between the content of two indices mentioned above and $\mathrm{N}$ enrichments and if negative influence on both markers could be detected under similar dose of $\mathrm{N}$ application.

Wang et al. [25] explored the symbiotic balance of dominant epiphytic lichens from the genera Usnea and Ramalina under the impact of added N. N uptake can change the photobiont-mycobiont ratio in many lichen species, but only Usnea longissima Ach. was able to maintain a stable balance between the bionts, being capable of regulating its $\mathrm{N}$ assimilation [25]. These authors stressed that changes in the balance between the bionts could affect lichen diversity. Better exploration of this topic seems to be very interesting challenge in future lichenological studies. For example, even if $\mathrm{N}$ in excess will be deleterious for the lichen symbiosis, it seems to be still weakly recognized in which extend the independence of photobionts will be crucial for their persistence and maintenance in the environment. More investigations of benefits and costs of symbiosis collapses for separated bionts should be also indicated.

A great many different secondary metabolites are produced as a result of lichen symbioses. Most lichen compounds are supplied by the fungal partner, and secondary metabolites are often accumulated in the upper part of the cortex and medullary layer of the lichen thallus or in some of its specialized structures, e.g., fruiting bodies [51,52]. The literature contains some contradictory results regarding changes in secondary metabolite production under excess nitrogen, so some research questions relating to this aspect remain to be addressed. Intensive treatments of Alectoria sarmentosa, Lobaria scrobiculata (Scop.) P. Gaertn., Platismatia glauca and Xanthoria aureola with $\mathrm{NH}_{4} \mathrm{NO}_{3}$ showed that all these lichens have a robust defence [22]. None of them significantly reduced the concentration of secondary compounds during the experimental period, although the concentration of all lichen compounds was significantly lower in N-treated thalli in Platismatia glauca [22]. Maslaňáková et al. [12], too, did not observe significantly different changes in the usnic acid concentration in Cladonia arbuscula ssp. mitis or in the content of fumarprotocetraric acid in Cladonia furcata under the impact of nitrogen 
exposure. On the other hand, after a spraying experiment with $\mathrm{NH}_{4} \mathrm{NO}_{3}$, an increase in parietin concentration in Xanthoria aureola was found [22]. Similarly, elevated nitrogen levels increased the chlorophyll a content, and therefore also the photosynthetic capacity and subsequently parietin production in Xanthoria parietina ([1] and the literature cited therein). Ammonia was found to affect Flavoparmelia caperata, among other things, by decreasing the usnic acid content in the thalli of this species, whereas the caperatic acid content remained stable [10]. The role of this latter secondary compound seems to be more important than that of usnic acid in this lichen's ability to cope with excess N [10]. Indications of lichens compounds under N input could increase our knowledge about lichen defense system against nitrogen pollution.

The production of secondary metabolites by the fungal partner is based on the use of fixed carbon (C) delivered by the photobiont. Increased anthropogenic $\mathrm{N}$ deposition in some ecosystems may affect the cycling of $\mathrm{C}$ and $\mathrm{N}$ in the lichen symbiosis and thus change the concentration of carbon-based secondary compounds (CBSCs). It is possible that both the amount of CBSCs and, for example, their antipathogenic activities, will result from the $\mathrm{C}$ and $\mathrm{N}$ status of lichens and be affected in environments with elevated nitrogen levels [22]. According to Johansson et al. [2], any increase in the photobiont: mycobiont ratio or parasitic fungal attacks that destabilize the lichen thallus may cause Alectoria sarmentosa to decline rapidly under N-elevated conditions. The fungal component forms the framework of the lichen thallus, which can be destabilized as a result of changes in the ratio between the bionts [2], whereas $\mathrm{N}$ availability may negatively influence the chemical defences of lichens, promoting the occurrence of parasites on their thalli $[2,53]$. Both factors could increase the fragility of the lichen thalli, which become less resistant to fragmentation in inclement weather [2].

\section{Growth of Lichens vs. Nitrogen Input}

The growth response to nitrogen has been well explored in such species as Xanthoria parietina $[31,38,54]$ and taxa from the genus Cladonia [55-58]. For example, medium nutrient application rates had a significant positive impact on the thallus growth of Flavoparmelia caperata, Parmelia saxatilis (L.) Ach. and Xanthoria parietina, whereas higher application frequencies retarded growth [54]. At higher nutrient levels, however, Xanthoria parietina exhibited a faster growth rate than lichens from the genera Flavoparmelia and Parmelia [54]. Excess $\mathrm{N}$ also accelerated the growth rate of another epiphytic species-Platismatia glauca-from 3 to $30 \%$ [45]. Vagts and Kinder [58] found that treatment with NPK-fertilizer promoted the growth of Cladonia portentosa (164\% of the control) and Cladonia furcata (144\% of the control), whereas the growth of the former species was inhibited ( $52 \%$ of the control) after the separate addition of $\mathrm{N}$. Application of organic fertilizers resulted in a distinct increase of Cladonia furcata with a growth of $3.4 \mathrm{~mm}$ per year compared to the control lichens, which grew at an average rate of ca $2.9 \mathrm{~mm}$ per year [57]. The dominance of Cladonia stellaris (Opiz) Pouzar \& Vézda over Stereocaulon paschale (L.) Hoffm. in the ground cover vegetation of dry boreal coniferous forests is probably linked to its more efficient nitrogen uptake and faster relative growth [59]. Since there are differences between bionts response to nitrogen supply, growth of lichens could be also analysed in relation to the growth of particular symbionts partners. It is still not clear if the growth of bionts can be linear and if its rate can varied between the mycobionts and photobionts.

Morphological characteristics of lichen thalli can also influence the $\mathrm{N}$ uptake. Johansson et al. [50] reported that the lower $\mathrm{N}$ uptake in Alectoria sarmentosa than in Platismatia glauca and Lobaria pulmonaria (L.) Hoffm. may be related to the pendulous growth form of the first-mentioned species owing to the limited absorbance of nutrients and the rapid runoff of water from the thallus instead of its remaining there.

The responses of all the above-mentioned species to $\mathrm{N}$ fertilization were examined in the context of $\mathrm{P}$ availability [50]. Photobiont growth in all the lichens studied was positively induced by the $\mathrm{N}$ supply, which may have resulted in more intensive photosynthesis and therefore increased carbon levels (input), as well as exhibiting a positive influence on mycobiont and thallus growth ([50] and the literature cited therein). However, the photobiont could also have displayed more independent growth, using more assimilated $C$ for its own requirements, as a result of which the mycobiont could 
have lost control over its autotroph partner, resulting in an unbalanced symbiosis ([50] the literature cited therein).

A four-year-long field $\mathrm{N}$ and $\mathrm{P}$ addition experiment on an upland moor showed that the lichen cover virtually disappeared as a result of nitrogen $(\mathrm{N})$ treatment [60]. However, the opposite effect was observed when phosphorus (P) was applied [60]. P limitation, in particular linked to enhanced $\mathrm{N}$ deposition, may cause lichens to disappear [60]. The restricted availability of $\mathrm{P}$ in the case of increased $\mathrm{N}$ deposition can be linked to the sensitivity of some lichens, e.g., Alectoria sarmentosa, to nitrogen pollution [50]. A similar effect, i.e., an increase in the N:P mass ratio and P-limitation, was detected in Cladonia portentosa as a result of elevated nitrogen deposition [28,61]. However, it was also observed that the nitrogen content in lichen thalli did not increase when $\mathrm{N}$ and $\mathrm{P}$ were used, probably because of the growth dilution of this compound after inducing thallus growth [28].

\section{Lichen Communities and Species in Response to Nitrogen Pollution}

Nitrogen pollution can result in loss of diversity and abundance (e.g., [2,7]), a shift from oligotrophilous towards nitrophilous communities (e.g., $[6,8,19,42,62-64])$, the disappearance or at least the declining abundance of some species sensitive to $\mathrm{N}$ pollution [2,15], and the spread of some other lichens adapted to $\mathrm{N}$-enriched habitats $[65,66]$. Although the impact of nutrient addition on lichen communities seems to be less well understood, it could pose a threat to biodiversity conservation (comp. [54]).

In their meta-analysis of the literature, Gutiérrez-Larruga et al. [35] found that the addition of N negatively influenced lichen abundance in the medium to long term. Eutrophication is indicated among the factors leading to a decrease in diversity [58]. In particular, epigeic lichens are likely to be threatened. The increased nutrient content of the substratum resulting from fertilization with nitrogen, for example, can reduce their occurrence and abundance and cause them to be displaced by intensively growing vascular plants and mosses [55-58]. More intense competition following nitrogen addition can lead to some lichen species being replaced by other lichens, mosses or plants. Intensified competition between Flavoparmelia caperata, Parmelia saxatilis and Xanthoria parietina was manifested by the significant increase in the number of thallus overlaps at medium nutrient applications [54]. Although Johansson et al. [2] found that a higher $\mathrm{N}$ supply (in concentrations equivalent to depositions of 25 and $50 \mathrm{~kg} \mathrm{~N} \mathrm{ha}^{-1} \mathrm{yr}^{-1}$ ) reduced the total lichen abundance, the opposite effect was observed when the $\mathrm{N}$ availability increased more slowly (in concentrations equivalent to depositions of 6 and $12.5 \mathrm{~kg} \mathrm{~N} \mathrm{ha}^{-1} \mathrm{yr}^{-1}$ ). Other studies also demonstrated that medium levels of nitrogen pollution could enhance lichen diversity. Such a situation may occur when the level of nitrogen input, while not yet exhibiting a detrimental effect on the presence of oligotrophilous lichens, is starting to promote the expansion of nitrophilous species. For example, Pinho et al. [63] found that traditional, low intensity land use (i.e., pasture activities) supported the increase in total species richness, since it allowed the coexistence of lichens with different trophic requirements, even if the abundance of $\mathrm{N}$-sensitive lichens was already starting to decline.

Lichens react to nitrogen pollution in a species-specific way that can change the species composition of lichen communities $[25,50]$. The response of individual species to nitrogen stress seems to be well documented (e.g., $[10,12,22,23,25,30,31,38,42,45,50,57])$. The occurrence of some recently described species, such as Lecanora barkmaneana Aptroot \& Herk [65] and Bacidina neosquamulosa (Aptroot \& van Herk) S. Ekman [66], was at least partially linked to increased $\mathrm{N}$ inputs in the environment. Both lichens are spreading, corticolous species that prefer enriched habitats, including those impacted by $\mathrm{NH}_{3}[65,66]$. The probability of the occurrence of sensitive lichens like Bryoria capillaris (Ach.) Brodo \& D. Hawksw., Bryoria fuscescens (Gyeln.) Brodo \& D. Hawksw., Vulpicida pinastri (Scop.) J.-E. Mattsson \& M.J. Lai, Imshaugia aleurites (Ach.) S.L.F. Meyer and Usnea hirta (L.) Weber ex F.H. Wigg. was less already at concentrations in precipitation as low as $0.3 \mathrm{mg} \mathrm{N} / 1$ [15]. 


\section{Functional Groups in Relation to Increasing N Deposition}

Lichen species differ in their sensitivity to anthropogenic disturbances [17]. Trophic functional groups are commonly adopted in lichenological studies: acidophilous (i.e., oligotrophic, acid-tolerant species, sensitive to nitrogen and requiring a low substrate $\mathrm{pH}$ ) and nitrophilous species (i.e., eutrophic, nitrogen-tolerant species, which benefit from eutrophication and dust) (comp. [26,67]). The range on a trophic requirement scale has been specified for some taxa as an ecological index. For example, Wirth [68] determined indicator values based on scale of 1-9 in relation to eutrophication. In contrast, Nimis [69] classified lichens into five groups, from not resistant to eutrophication to occurring in highly eutrophic habitats. Verein Deutscher Ingenieure (VDI) [67] proposed to use diversity values of lichen species regarded as indicators of eutrophication and of other taxa (i.e., reference species) during bioindication studies aimed at assessing and evaluating air quality. Giordani et al. [70] made an attempt to establish an ecological gradient for eutrophication in Liguria (north-western Italy); its low value in the region was associated with the lack of intensive agriculture.

Barkman [71] back in 1958 indicated the presence of nitrophilous lichens when characterizing the Xanthorion parietinae alliance. Later studies focusing on the species composition of syntaxa and substrate $\mathrm{pH}$ made reference to these comments about epiphytic communities containing nitrophilous species in the agricultural landscape [6,33].

Excess $\mathrm{N}$ drives changes in the lichen biota species composition. Elevated nitrogen deposition favours the presence of more $\mathrm{N}$-tolerant species. The increase in the number of indicators of eutrophication on acidic trees in central Europe has resulted from the declining concentrations of acidifying air pollutants and the increasing levels of airborne nutrients since the 1980s [67]. Ammonia pollution on the lower Wilson River (Oregon, OR, USA) was probably responsible for the abundance of nitrophilous and the absence of epiphytic cyanolichens and lichens normally occupying substrates with lower $\mathrm{pH}$ [62]. Ammonia generates changes in the lichen biota composition that are manifested by the increase or decrease in the proportion of nitro- or acidophilous lichens, respectively, especially in open, mainly farmland areas $[8,16,19,33,63,72]$. A complete shift from oligotrophilous to nitrophilous lichens was reported as close as $65 \mathrm{~m}$ from a $\mathrm{NH}_{3}$ source, owing to increasing concentrations of this $\mathrm{N}$ form [24]. An increase in nitrophilous lichens growing on tree bark within $200 \mathrm{~m}$ of an industrial facility composting organic waste was observed after three years of operation [42]. The diversity of strictly nitrophilous lichens growing around a pig stockfarm in central Italy was positively influenced by both $\mathrm{NH}_{3}$ and bark $\mathrm{pH}$ [23]. However, the effect of the former factor on the nitrophilous lichen diversity and the total lichen diversity was not confirmed [23].

At least some acidophilous lichens respond negatively to an elevated ammonium content in substrates, a rise in $\mathrm{pH}$ and the intensive development of other organisms competing for a shared niche $[8,15]$. The frequency of oligotrophilous species was negatively correlated with land use intensity [63]. The oligotrophic component of epilithic lichen communities was found to be the most sensitive functional group because of the impact of increasing $\mathrm{N}$ availability in alpine pasturelands in western Italy [64]. A significant decrease in the relative frequency of oligotrophilous lichens was linked to an increase in the total number of adult cattle units [64]. The abundance of species from this trophic group was lower in comparison with nitrophilous lichens growing in the Po Plain in north-western Italy, where eutrophication levels are high [27].

According to Jovan et al. [26], "weedy" eutrophic species tend to replace native lichens where nitrogen $(\mathrm{N})$ input is excessive. However, Pinho et al. [63] demonstrated that where the level of disturbance is intermediate, i.e., medium levels of atmospheric ammonia, species can coexist, and sensitive lichens can also persist. An investigation of species diversity along a gradient of low-intensity land-use (forestry and pasture activities) showed that the total species richness was positively correlated with an increase of nitrophilous species together with the maintenance of oligotrophilous species richness [63]. Similarly, the lichenological inventory in the Netherlands revealed that $\mathrm{NH}_{3}$ contributes to a shift in the lichen composition, promoting acidiphobous species at the expense of acidophilous lichens, rather than reducing the total number of species [73]. Frati et al. [23] also emphasized the less pronounced effect 
of $\mathrm{NH}_{3}$ on lichens growing on oaks around a pig stockfarm; this study reported a shift in species composition from neutrophilous-nitrophilous to strictly nitrophilous species instead of from acidophilous to nitrophilous species.

Frahm [11] investigated the amino acid content in lichens with different levels of N-tolerance. It was found that the nitrophily of the species did not influence the variance in the amino acid content [11]. However, this content seems to depend on the atmospheric nitrogen load; a higher value was detected in more seriously $\mathrm{N}$-impacted regions [11]. On the other hand, nitrophilous lichens exhibited a higher cell liquid conductivity (a measure of osmotic stress) than other species. Therefore, according to Frahm [11], the term "nitrophily" should refer to species that probably display osmotic tolerance against the salt effects of nitrogen compounds rather than be linked with the ability to take up higher amounts of nitrogen. Without mechanisms that control nitrogen uptake, species store surplus nitrogen as amino acid. The higher osmotic values of nitrophilous lichens strengthens their competitive advantage in regions with low humidity owing to their ability to absorb water vapour in drier conditions [11]. This feature seems to vary among nitrophilous species and is associated with their tolerance to dry deposition [11].

\section{Lichens as Indicators of Air Pollution with Nitrogen Compounds}

For a long time, sulphur dioxide air pollution was regarded as one of the major drivers influencing the occurrence and abundance of lichenized fungi. However, recent changes in lichen communities from oligo- to nitrophilous as a result of elevated nitrogen deposition have attracted attention: the indicator role of lichens, especially epiphytes, in the detection of the nitrogen impact is now better recognized (e.g., $[7,8,15,16,19,23,24,39,74-77])$. The relatively fast response of lichens to the $\mathrm{N}$ enrichment of habitats can now be detected at the physiological, biont, species and community levels, as described earlier.

On the basis of a meta-analysis of the literature about the effects of experimental $\mathrm{N}$ fertilization on lichen abundance and metabolism, Gutiérrez-Larruga et al. [35] found that most detrimental effects occurred in relation to both terricolous and epiphytic lichens with green algae as the photobiont. Several studies aimed at determining the effect of $\mathrm{N}$ pollution on the lichen biota in the agricultural landscape were based on measurements of species richness and abundance (Table 1) (e.g., $[6-8,23,27,64,73,77,78])$. As long ago as the mid-1980s, certain symptoms of lichen stress induced by ammonia pollution were observed in the Netherlands $[8,16]$. The effect of this compound was mapped based on the frequency of nitro- (NIW, "Nitrofiele Indicatie Waarde") and acidophilous (AIW, "Acidophiele Indicatie Waarde") species [8]. VDI [67] recommended a standardized method that applied diversity values of lichen species regarded as indicators of eutrophication and of other taxa (i.e., reference species) during bioindication studies undertaken to assess and evaluate air quality. Lichen species promoted by elevated nitrogen levels, in particular Phaeophyscia nigricans (Flörke) Moberg, Phaeophyscia orbicularis (Neck.) Moberg, Physcia adscendens (Fr.) H. Olivier, Physcia dubia (Hoffm.) Lettau, Physcia tenella (Scop.) DC., Xanthoria candelaria (L.) Th. Fr., Xanthoria parietina, and Xanthoria polycarpa (Hoffm.) Rieber were indicated in several papers (Table 2). In particular, nitrophilous lichens previously absent or scarce on trees with acid bark, were becoming a more common component of the lichen biota found there $[8,33]$. Therefore, special attention should be paid to selected phorophytes with physical and chemical properties suitable for biomonitoring purposes [67,79]. Oaks, including Quercus pubescens Willd. [6,23], Quercus robur L. [8,16] and Quercus suber L. [24,72], are among the more common trees investigated in monitoring studies analysing the impact of nitrogen input on epiphytic lichens [19].

In general, anthropogenic disturbances impoverish the lichen biota. However, the effect of $\mathrm{N}$ pollution is not so obvious, especially when the impact of low or medium levels of elevated nitrogen is analysed. For example, Frati et al. [23] investigated the diversity of epiphytic lichens around a pig stockfarm in relation to high ammonia and nitrogen deposition. They found no correlation between the total lichen diversity and $\mathrm{NH}_{3}$ concentrations or bark $\mathrm{pH}$, although the diversity of strictly nitrophilous species was positively associated with $\mathrm{NH}_{3}$ and bark $\mathrm{pH}$. Johansson et al. [2] emphasized the importance of the study period and the necessity to consider cumulative loads of 
pollution. Short-term studies cannot capture the more detrimental effects of $\mathrm{N}$ pollution on lichens that may occur in the longer term [2]. For examples, Johansson et al. [2] reported that in the first year of higher nitrogen treatments, the abundance of Alectoria sarmentosa increased, but subsequently, the species declined rapidly.

Table 1. Bioindication studies investigating the response of lichens to $\mathrm{N}$ pollution, at least partially carried out in an agricultural landscape (a reference list).

\begin{tabular}{|c|c|c|c|c|}
\hline $\begin{array}{l}\text { Response } \\
\text { Level }\end{array}$ & Species Investigated/Measurements & Pollutant(-s) & Country & References \\
\hline Biont & $\begin{array}{c}\text { Xanthoria parietina; chlorophyll a, } \\
\text { ergosterol }\end{array}$ & $\mathrm{N}$ pollution & Portugal & {$[38]$} \\
\hline \multirow[t]{5}{*}{ Species } & Physcia caesia, $\mathrm{N}$ content in the thalli & $\begin{array}{c}\mathrm{N} \text { emissions } \\
\mathrm{NH}_{2} \text { pollution and }\end{array}$ & Switzerland & [7] \\
\hline & $\begin{array}{l}\text { X. parietina, Flavoparmelia caperata; } \\
\text { total } \mathrm{N} \text { accumulated in the thalli }\end{array}$ & $\begin{array}{l}\text { nitrogen deposition } \\
\text { around a pig } \\
\text { stockfarm }\end{array}$ & Italy & [23] \\
\hline & $\begin{array}{l}\text { X. parietina; specific weight of thallus, } \\
\text { concentration of total } \mathrm{N}\end{array}$ & $\mathrm{N}$ pollution & Portugal & {$[38]$} \\
\hline & $\begin{array}{c}\text { Evernia prunastri, Pseudevernia } \\
\text { furfuracea; photosynthetic } \\
\text { performance }\end{array}$ & $\begin{array}{l}\mathrm{NH}_{3} \text { pollution } \\
\text { around a sheep farm }\end{array}$ & Greece (Crete) & [9] \\
\hline & $\begin{array}{c}\text { Evernia prunastri, Hypogymnia } \\
\text { physodes, Parmelia sulcata, Physcia } \\
\text { adscendens, Xanthoria parietina; the } \\
\text { amino acid content }\end{array}$ & $\begin{array}{l}\text { atmospheric } \mathrm{N} \\
\text { depositions }\end{array}$ & $\begin{array}{l}\text { Germany and } \\
\text { NW France }\end{array}$ & [11] \\
\hline \multirow[t]{8}{*}{ Community } & $\begin{array}{l}\text { Epiphytic lichen vegetation, } \\
\text { nitrophilous lichen species, Index of } \\
\text { Atmospheric Purity method }\end{array}$ & $\begin{array}{l}\text { fertilizers and } \mathrm{NH}_{3} \\
\text { emissions }\end{array}$ & Italy & [6] \\
\hline & $\begin{array}{l}\text { Presence and abundance of lichen } \\
\text { species on wayside trees }\end{array}$ & $\mathrm{SO}_{2}, \mathrm{NO}_{2}, \mathrm{NH}_{3}$ & Netherlands & [73] \\
\hline & $\begin{array}{l}\text { Frequency of some nitrophilous and } \\
\text { acidophilous species on the bark of } \\
\text { Quercus robur }\end{array}$ & $\mathrm{NH}_{3}$ pollution & Netherlands & [8] \\
\hline & $\begin{array}{l}\text { Diversity of epiphytic lichens, with } \\
\text { regard to nitrophilous, strictly } \\
\text { nitrophilous and non-nitrophilous } \\
\text { species }\end{array}$ & $\begin{array}{l}\mathrm{NH}_{3} \text { pollution and } \mathrm{N} \\
\text { deposition around a } \\
\text { pig-stockfarm }\end{array}$ & Italy & [23] \\
\hline & $\begin{array}{c}\text { Lichen vegetation, species frequency, } \\
\text { Nitroindex }\end{array}$ & $\mathrm{NH}_{3}$ pollution & Switzerland & [78] \\
\hline & $\begin{array}{l}\text { LDV, species diversity, nitrophilous } \\
\text { and reference species }\end{array}$ & Eutrophication & Poland & [77] \\
\hline & $\begin{array}{l}\text { Diversity and lichen functional } \\
\text { groups, epilithic lichen communities }\end{array}$ & $\begin{array}{c}\text { Pasture-derived N } \\
\text { deposition }\end{array}$ & Italy & [64] \\
\hline & $\begin{array}{l}\text { Abundance of lichen species, Lichen } \\
\text { Diversity Value (LDV), diversity of } \\
\text { functional groups }\end{array}$ & Eutrophication & Italy & [27] \\
\hline
\end{tabular}

Several studies have pointed out some lichen species as good bioindicators of N pollution, for example, Physcia caesia ( $\mathrm{N}$ deposition, [7]), Physconia grisea $\left(\mathrm{NH}_{3}\right.$ pollution, [23]), Xanthoria parietina ( $\mathrm{N}$ deposition, especially in relation to ammonia sources, [37]) and even the non-nitrophilous lichen Hypogymnia physodes (total nitrogen deposition, [5]). Among these species, Xanhoria parietina is commonly used in bioindication and bioaccumulation studies (Table 1), owing to its widespread distribution, similar $\mathrm{N}$ concentrations in different part of the thalli, and the detection of various nitrogen pollution emitters [37]. A very high tolerance of Xanthoria parietina to N pollution was confirmed by Gaio-Oliveira et al. [31], who found that this lichen species tolerated a weakly irrigation of at least $0.17 \mathrm{M} \mathrm{NH}_{4} \mathrm{Cl}$, corresponding to an $\mathrm{N}$ deposition of ca $1000 \mathrm{~kg} \mathrm{ha}^{-1} \mathrm{yr}^{-1}$. 
Table 2. Lichen species/genus considered as: (1) nitrophytes by van Herk [8], (2) eutrophication indicators by Verein Deutscher Ingenieure (VDI) [67], and (3) epiphytic lichens from central Europe tolerant to high nitrogen levels by Hauck [1].

\begin{tabular}{|c|c|c|c|}
\hline Lichen Species/Genus & 1 & 2 & 3 \\
\hline Amandinea punctata (Hoffm.) Coppins \& Scheid. & . & . & + \\
\hline Buellia griseovirens (Turner \& Borrer ex Sm.) Almb. & . & . & + \\
\hline Caloplaca citrina (Hoffm.) Th. Fr. & + & + & . \\
\hline C. holocarpa (Hoffm.) Wade & + & + & . \\
\hline Candelaria concolor (Dicks.) Stein & . & . & + \\
\hline Candelariella aurella (Hoffm.) Zahlbr. & + & . & . \\
\hline C. reflexa (Nyl.) Lettau & + & . & + \\
\hline C. vitellina (Hoffm.) Müll. Arg. & + & . & + \\
\hline C. xanthostigma (Ach.) Lettau & + & . & + \\
\hline Hyperhyscia adglutinata (Flörke) H. Mayrhofer \& Poelt & . & . & + \\
\hline Lecania cyrtella (Ach.) Th. Fr. & . & . & + \\
\hline Lecanora dispersa (Pers.) Sommerf. & + & + & . \\
\hline L. hagenii (Ach.) Ach. & + & + & . \\
\hline L. muralis (Schreb.) Rabenh. & + & + & . \\
\hline Phaeophyscia nigricans & + & + & + \\
\hline P.orbicularis & + & + & + \\
\hline Physcia adscendens & + & + & + \\
\hline P. caesia & + & + & . \\
\hline P. dubia & + & + & + \\
\hline P. tenella & + & + & + \\
\hline Physconia enteroxantha (Nyl.) Poelt & . & . & + \\
\hline P. grisea (Lam.) Poelt & . & + & + \\
\hline Rinodina spp. & . & + & . \\
\hline R. gennarii Bagl. & + & . & . \\
\hline R. pityrea Ropin \& Mayrhofer & . & . & + \\
\hline Xanthoria candelaria & + & + & + \\
\hline X. calcicola Oxner & + & . & . \\
\hline X.parietina & + & + & + \\
\hline X.polycarpa & + & + & + \\
\hline
\end{tabular}

Physiological metabolic responses [35], the parameter PIABS (a global index of photosynthetic performance) [9], the amino acid contents of lichens [11], the photobiont to mycobiont ratio [25], the diversity of strictly nitrophilous species (ILDsn) [23] and the abundance of epiphytic nitrophilous lichens [8] or lichen functional groups $[8,27,64]$ have all been proposed as further indicators of $\mathrm{N}$ pollution.

The use of lichens, especially in terms of their diversity and functional groups, as nitrogen indicators are widely recognized. Some transplants experiments in the field conditions could allow for better understanding of the response on the physiological levels in particular lichen species. Moreover, more regional investigations focus on the detection of distance at which shift from oligotrophilous to nitrophilous lichens can be reported could be a source of relevant information for environmental management. Location of local investments being a point source of $\mathrm{N}$ to environment in areas recognized as important to maintenance rich and diverse lichen biota could be preceded by the analyses such distance by administrative decision makers.

Several lichenological studies aimed at determining the critical nitrogen load and the critical level in relation to lichen biota. Such analyses considering lichens as very sensitive bioindicators could be helpful also in the protection of other groups of organisms from adverse effect of $\mathrm{N}$ pollution [80]. The critical load (CLO) is "a quantitative estimate of deposition of one or more pollutants below which significant harmful effects on specified elements of the environment do not occur according to present knowledge" (Posthumus, 1988: in [81]). Whereas critical levels (CLEs) indicate the concentration of pollutants in the atmosphere above which unfavourable impact occur (Cape et al., 2009: in [81]). The calculated empirical critical load and levels for $\mathrm{NH}_{3}$ can be used as a tool important in land management and for protecting vulnerable ecosystems [26,46,80,82]. 
Jovan et al. [26] underlined that empirical critical levels (CLE) for $\mathrm{NH}_{3}$ and critical loads (CLO) for $\mathrm{N}$ must strongly mediate the response of lichens to causal pollutant(s). Eutrophic species, commonly used in assessments of ecosystem change resulting from nitrogen enrichment, are likely to react to multiple forms of $\mathrm{N}$ instead of just $\mathrm{NH}_{3}$ and their abundance has been found to be driven primarily by $\mathrm{N}$ inputs rather than substrate $\mathrm{pH}$. Munzi et al. [46] recommended that critical levels should be calculated for $\mathrm{NH}_{3}$ with regard to oligotrophilous lichen species, as they are sensitive to the increasing availability of this pollutant. Giordani et al. [64] investigated epilithic lichen communities in the pasturelands of the Maritime Alps (NW Italy) and found that the oligotrophilous component was the functional group most sensitive to nitrogen. An increase in the total number of adult cattle units caused the relative frequency of oligotrophilous lichens to decrease [64]. The critical cattle load of the area was established at 0.12 grazing animals per hectare; above this value, the relative frequency of oligotrophilous lichens decreased sharply, and at a level of at least $0.25 \mathrm{ACU}$, they all but disappeared [64]. Also, Pinho et al. [82] considered diversity value of oligotrophilous lichens as the most sensitive lichen trophic groups when determined the CLO and CLE for semi-natural Mediterranean evergreen woodlands.

The epiphytic macrolichen community was used to calculate CLs (critical loads) for north-western North America's maritime forest [83]. CLs of 1-4 and 3-9 $\mathrm{kg} \mathrm{N} \mathrm{ha}^{-1} \mathrm{y}^{-1}$ in wet and total deposition resulted in a decline of sensitive species by $20-40 \%$ [83]. It was also found that precipitation can mitigate the effect of nitrogen pollution, probably due to the dilution or leaching of depositional $\mathrm{N}$ [83]. A significant decrease in the percentage of epiphytic macrolichens found at selected ForestBIOTA plots from 10 European countries was related to a critical load of $2.4 \mathrm{~kg} \mathrm{~N} \mathrm{ha}^{-1} \mathrm{yr}^{-1}$ [81]. Results from this study based on the analysis of the relative diversity of morpho-functional groups of epiphytic lichens in relation to nitrogen deposition indicated approx. $75 \%$ of the sampled plots in European forests affecting by high throughfall nitrogen deposition, mainly located in the Netherlands, Germany and Denmark [81]. Community investigations of lichens in California mixed conifer forests allowed to determine empirical CL of $3.1 \mathrm{~kg} \mathrm{ha}^{-1} \mathrm{yr}^{-1}$ for forest ecosystem [80]. Significant changes in lichen indicator groups in much of the western Sierra Nevada (USA) were linked to higher N deposition, i.e., $17 \mathrm{~kg} \mathrm{~N} \mathrm{ha}^{-1} \mathrm{yr}^{-1}$ [80]. Similarly, Pinho et al. [82] evaluated the critical load of $\mathrm{N}$ deposition and long-term critical levels of atmospheric ammonia for semi-natural Mediterranean evergreen cork-oak woodlands considering changes in epiphytic lichen communities in relation to trophic functional groups. These analyses showed that the critical load was lower than $26 \mathrm{~kg}(\mathrm{~N}) \mathrm{ha}^{-1} \mathrm{yr}^{-1}$, while the critical level was below $1.9 \mathrm{\mu g} \mathrm{m}^{-3}$ [82]. Critical load exceedances can be also evaluated in relation to some lichen species by determining nitrogen concentrations in their thalli. Letharia vulpina (L.) Hue, or wolf lichens, is one of them. $\mathrm{N}$ concentrations in its thalli on the levels of $1.0 \%$ was found to be indicative of CL exceedance [80]. Although CLOs and CLEs seems to be independent from climate, the management intensity can influence at least on CLOs ([82] and the literature cited therein). Therefore, some future studies could include more investigations of critical loads and levels in sites under different management regimes.

\section{Knowledge Gaps and Recommendations}

Although several papers on lichen chemistry impacted by $\mathrm{N}$ have recently been published, knowledge of this topic remains incomplete; here, the study of the relationships between the composition and contents of lichen substances and the presence of lichenicolous fungi in the context of elevated nitrogen deposition is recommended. So far, there has been little scientific interest in identifying the chemical responses of lichens and their physiological reactions to stress induced by excess nitrogen input, although certain parameters in some species have been more extensively investigated (e.g., $[2,22,31,38,42])$. Nybakken et al. [22] stressed that changes in carbon-based secondary metabolite concentrations in conditions of elevated nitrogen deposition are still poorly researched, and indicated the need for field experiments. With regard to environmental variables that influence the production of secondary metabolites, it is mainly abiotic parameters that are studied; information about the correlations between biotic factors and the presence and production of lichen compounds is scanty. 
As regards lichen chemistry, it would be interesting to discover whether excess nitrogen could increase the production of pharmaceutically and biotechnologically interesting secondary metabolites. Detailed qualitative and quantitative analyses of changes in the concentrations of lichen acids under the influence of nitrogen, together with the investigation of other physiological parameters, should support efforts in the biotechnological cultivation of these organisms to obtain desirable secondary constituents. Their functions in natural processes should be considered and observed when their biological activity is investigated [52].

Only a few studies have linked the adaptation of lichen substances to environmental changes [84]. Unanswered questions relate to the production of secondary compounds in the context of adaptation to an eutrophic environment. Information is scanty and incomplete about the co-occurrence of secondary metabolites regarding their linked role, if it exists, in mitigating the negative impacts of environmental disturbances and, hence, their ability to adapt to different habitats. Lichens are commonly regarded as indicators of anthropogenic impact, mainly associated with air pollution. Future studies should therefore extend knowledge about changes in the activity and production of selected physiological parameters, including lichen constituents subject to anthropogenic pressure, related to excessive nitrogen supplies. The results could be used to assess their values for bioindication and biomonitoring purposes. Other authors $[1,20,31]$ have pointed out the need for a better understanding of the protective role of secondary compounds in the $\mathrm{N}$-induced responses of lichens.

Further important research questions have already been identified in the literature. For example, Gaio-Oliveira et al. [31] encouraged the analysis of the response of particular species to a N supply. Determining the tolerance of different species to toxicity, and indicating their sensitivity to N pollution, could expand existing knowledge about living organisms affected by air pollution. The impact of particular forms of nitrogen on lichen biota also needs to be clarified. Studies focused on the symbiotic balance could help to better understand the mechanism of $\mathrm{N}$ stress on lichen diversity, as well as the sensitivity of ecologically beneficial lichens to nitrogen (cf. [20,34]). Paoli et al. [10] recommended conducting controlled experiments enabling the direct influence of nitrogen on lichens to be detected; in this way the risk of the influence of environmental factors on $\mathrm{N}$ uptake would be at least minimized or even avoided altogether. Hauck [1] outlined the need to study the effect of $\mathrm{N}$ on lichens based in particular on the recognition of the role of, for example, (a) light influx on tolerance to ammonium and nitrate, (b) green-algal photobionts with respect to their tolerance to excess nitrogen, and (c) ammonium adsorption in the context of apoplastic $\mathrm{pH}$ and metal concentrations. Lichens are highly sensitive to air pollution, so their utility in calculating critical loads (cf. [9]), which still need to be measured in different parts of the world and in various environments, could be a helpful tool for environmental managers when taking action to prevent biodiversity loss due to elevated nitrogen deposition (e.g., [2,26]).

Funding: This research was funded by statutory funds.

Acknowledgments: I would like to thank the reviewers and the Assistant Editor for careful and thorough reading of the manuscript and for the comments and constructive suggestions. I am grateful to Peter Senn for extensive editing of English language.

Conflicts of Interest: The author declare no conflict of interest.

\section{References}

1. Hauck, M. Ammonium and nitrate tolerance in lichens. Environ. Pollut. 2010, 158, 1127-1133. [CrossRef] [PubMed]

2. Johansson, O.; Palmqvist, K.; Olofsson, J. Nitrogen deposition drives lichen community changes through differential species responses. Glob. Chang. Biol. 2012, 18, 2626-2635. [CrossRef]

3. Engardt, M.; Simpson, D.; Schwikowski, M.; Granat, L. Deposition of sulphur and nitrogen in Europe 1900-2050. Model calculations and comparison to historical observations. Tellus B Chem. Phys. Meteorol. 2017, 69, 1328945. [CrossRef] 
4. Galloway, J.N.; Dentener, F.J.; Capone, D.G.; Boyer, E.W.; Howarth, R.W.; Seitzinger, S.P.; Asner, G.P.; Cleveland, C.C.; Green, P.A.; Holland, E.A.; et al. Nitrogen cycles: Past, present and future. Biogeochemistry 2004, 70, 153-226. [CrossRef]

5. Søchting, U. Lichens as monitors of nitrogen deposition. Cryptogam. Bot. 1995, 5, 264-269.

6. Loppi, S.; de Dominicis, V. Effects of agriculture on epiphytic lichen vegetation in central Italy. Isr. J. Plant. Sci. 1996, 44, 297-307. [CrossRef]

7. Ruoss, E. How agriculture affects lichen vegetation in central Switzerland. Lichenologist 1999, 31, 63-73. [CrossRef]

8. Van Herk, C.M. Mapping of ammonia pollution with epiphytic lichens in the Netherlands. Lichenologist 1999, 31, 9-20. [CrossRef]

9. Paoli, L.; Pirintsos, S.A.; Kotzabasis, K.; Pisani, T.; Navakoudis, E.; Loppi, S. Effects of ammonia from livestock farming on lichen photosynthesis. Environ. Pollut. 2010, 158, 2258-2265. [CrossRef]

10. Paoli, L.; Maslaňáková, I.; Grassi, A.; Bačkor, M.; Loppi, S. Effects of acute $\mathrm{NH}_{3}$ air pollution on $\mathrm{N}$-sensitive and N-tolerant lichen species. Ecotoxicol. Environ. Saf. 2015, 122, 377-383. [CrossRef]

11. Frahm, J. Contents of amino acids and osmotic values of epiphytic lichens as indicators for regional atmospheric nitrogen loads. Arch. Lichenol. 2013, 9, 1-11.

12. Maslaňáková, I.; Bil'ová, I.; Goga, M.; Kuchár, M.; Bačkor, M. Differences between sensitivity of mycobiont and photobiont of Cladonia sp. lichens to different types of nitrogen exposure. Water Air. Soil Pollut. 2015, 226, 243. [CrossRef]

13. Zeng, Y.; De Guardia, A.; Ziebal, C.; De Macedo, F.J.; Dabert, P. Nitrification and microbiological evolution during aerobic treatment of municipal solid wastes. Bioresour. Technol. 2012, 110, 144-152. [CrossRef] [PubMed]

14. Erisman, J.W.; Dammers, E.; Van Damme, M.; Soudzilovskaia, N.; Schaap, M. Trends in EU nitrogen deposition and impacts on ecosystems. EM (Pittsburgh Pa) 2015, 65, 31-35.

15. Van Herk, C.M.; Mathijssen-Spiekman, E.A.M.; de Zwart, D. Long distance nitrogen air pollution effects on lichens in Europe. Lichenologist 2003, 35, 347-359. [CrossRef]

16. Van Herk, C.M. Bark $\mathrm{pH}$ and susceptibility to toxic air pollutants as independent causes of changes in epiphytic lichen composition in space and time. Lichenologist 2001, 33, 419-441. [CrossRef]

17. Nash, T.H. Lichens as indicators of air pollution. In The Handbook of Environmental Chemistry. Air Pollution; Hutzinger, O., Ed.; Springer: Berlin/Heidelberg, Germany, 1991; Volume 4, pp. 1-29.

18. Frati, L.; Caprasecca, E.; Santoni, S.; Gaggi, C.; Guttova, A.; Gaudino, S.; Pati, A.; Rosamilia, S.; Pirintsos, S.A.; Loppi, S. Effects of $\mathrm{NO}_{2}$ and $\mathrm{NH}_{3}$ from road traffic on epiphytic lichens. Environ. Pollut. 2006, 142, 58-64. [CrossRef]

19. Wolseley, P.; James, P.W.; Theobald, M.R.; Sutton, M.A. Detecting changes in epiphytic lichen communities at sites affected by atmospheric ammonia from agricultural sources. Lichenologist 2006, 38, 161-176. [CrossRef]

20. Carter, T.S.; Clark, C.M.; Fenn, M.E.; Jovan, S.; Perakis, S.S.; Riddell, J.; Schaberg, P.G.; Greaver, T.L.; Hastings, M.G. Mechanisms of nitrogen deposition effects on temperate forest lichens and trees. Ecosphere 2017, 8, e01717. [CrossRef]

21. Guthrie, S.; Giles, S.; Dunkerley, F.; Tabaqchali, H.; Harshfield, A.; Loppolo, B.; Manville, C. The Impact of Ammonia Emissions from Agriculture on Biodiversity. An Evidence Synthesis; RAND Corporation: Cambridge, UK; The Royal Society: London, UK, 2018.

22. Nybakken, L.; Johansson, O.; Palmqvist, K. Defensive compound concentration in boreal lichens in response to simulated nitrogen deposition. Glob. Chang. Biol. 2009, 15, 2247-2260. [CrossRef]

23. Frati, L.; Santoni, S.; Nicolardi, V.; Gaggi, C.; Brunialti, G.; Guttová, A.; Gaudino, S.; Pati, A.; Pirintsos, S.A.; Loppi, S. Lichen biomonitoring of ammonia emission and nitrogen deposition around a pig stockfarm. Environ. Pollut. 2007, 146, 311-316. [CrossRef] [PubMed]

24. Pinho, P.; Dias, T.; Cruz, C.; Sim Tang, Y.; Sutton, M.A.; Martins-Loução, M.A.; Máguas, C.; Branquinho, C. Using lichen functional diversity to assess the effects of atmospheric ammonia in Mediterranean woodlands. J. Appl. Ecol. 2011, 48, 1107-1116. [CrossRef]

25. Wang, M.; Wang, C.; Jia, R. The impact of nitrogen deposition on photobiont-mycobiont balance of epiphytic lichens in subtropical forests of central China. Ecol. Evol. 2019, 9, 13468-13476. [CrossRef] [PubMed]

26. Jovan, S.; Riddell, J.; Padgett, P.E.; Nash III, T.H. Eutrophic lichens respond to multiple forms of N: Implications for critical levels and critical loads research. Ecol. Appl. 2012, 22, 1910-1922. [CrossRef] [PubMed] 
27. Giordani, P.; Malaspina, P. Do tree-related factors mediate the response of lichen functional groups to eutrophication? Plant. Biosyst. 2017, 151, 1062-1072. [CrossRef]

28. Hogan, E.J.; Minnullina, G.; Sheppard, L.J.; Leith, I.D.; Crittenden, P.D. Response of phosphomonoesterase activity in the lichen Cladonia portentosa to nitrogen and phosphorus enrichment in a field manipulation experiment. New Phytol. 2010, 186, 926-933. [CrossRef] [PubMed]

29. Johansson, O.; Nordin, A.; Olofsson, J.; Palmqvist, K. Responses of epiphytic lichens to an experimental whole-tree nitrogen-deposition gradient. New Phytol. 2010, 188, 1075-1084. [CrossRef]

30. Bruteig, I.E. The epiphytic lichen Hypogymnia physodes as a biomonitor of atmospheric nitrogen and sulphur deposition in Norway. Environ. Monit. Assess. 1993, 26, 27-47. [CrossRef]

31. Gaio-Oliveira, G.; Dahlman, L.; Palmqvist, K.; Máguas, C. Ammonium uptake in the nitrophytic lichen Xanthoria parietina and its effects on vitality and balance between symbionts. Lichenologist 2004, 36, 75-86. [CrossRef]

32. Gilbert, O. An alkaline dust effect on epiphytic lichens. Lichenologist 1976, 8, 173-178. [CrossRef]

33. Frati, L.; Brunialti, G.; Loppi, S. Effects of reduced nitrogen compounds on epiphytic lichen communities in Mediterranean Italy. Sci. Total Environ. 2008, 407, 630-637. [CrossRef]

34. Oliver, M. Canaries in a Coal Mine: Using lichens to measure nitrogen pollution. Sci. Find. 2011, 131, 1-6.

35. Gutiérrez-Larruga, B.; Estébanez-Pérez, B.; Ochoa-Hueso, R. Effects of nitrogen deposition on the abundance and metabolism of lichens: A meta-analysis. Ecosystems 2020, 23, 783-797. [CrossRef]

36. Hauck, M.; Wirth, V. Preference of lichens for shady habitats is correlated with intolerance to high nitrogen levels. Lichenologist 2010, 42, 475-484. [CrossRef]

37. Gaio-Oliveira, G.; Branquinho, C.; Máguas, C.; Martins-Louçāo, M.A. The concentration of nitrogen in nitrophilous and non-nitrophilos lichen species. Symbiosis 2001, 31, 187-199.

38. Gaio-Oliveira, G.; Dahlman, L.; Palmqvist, K.; Máguas, C. Responses of the lichen Xanthoria parietina (L.) Th.Fr. to varying thallus nitrogen concentrations. Lichenologist 2005, 37, 171-179. [CrossRef]

39. Wolseley, P.A.; Leith, I.D.; van Dijk, N.; Sutton, M.A. Macrolichens on twigs and trunks as indicators of ammonia concentrations across the UK-A practical method. In Atmospheric Ammonia; Sutton, M., Reis, S., Baker, S.M.H., Eds.; Springer Sciences+Business Media, B.V.: Dordrecht, The Netherlands, 2009; pp. 101-108.

40. Stofer, S.; Bergamini, A.; Aragón, G.; Carvalho, P.; Coppins, B.F.; Davey, S.; Dietrich, M.; Farkas, E.; Kärkkäinen, K.; Keller, C.; et al. Species richness of lichen functional groups in relation to land use intensity. Lichenologist 2006, 38, 331-353. [CrossRef]

41. Hawksworth, D.L. The variety of fungal-algal symbioses, their evolutionary significance, and the nature of lichens. Bot. J. Linn. Soc. 1988, 96, 3-20. [CrossRef]

42. Paoli, L.; Benesperi, R.; Proietti Pannunzi, D.; Corsini, A.; Loppi, S. Biological effects of ammonia released from a composting plant assessed with lichens. Environ. Sci. Pollut. Res. 2014, 21, 5861-5872. [CrossRef]

43. Bargagli, R.; Mikhailova, I. Accumulation of inorganic contaminants. In Monitoring with Lichens-Monitoring Lichens; NATO Science Series, IV. Earth and Environmental Sciences; Nimis, P.L., Scheidegger, C., Wolseley, P.A., Eds.; Springer: Berlin/Heidelberg, Germany, 2002; Volume 7, pp. 65-84.

44. Pirintsos, S.A.; Munzi, S.; Loppi, S.; Kotzabasis, K. Do polyamines alter the sensitivity of lichens to nitrogen stress? Ecotoxicol. Environ. Saf. 2009, 72, 1331-1336. [CrossRef]

45. Palmqvist, K.; Dahlman, L. Responses of the green algal foliose lichen Platismatia glauca to increased nitrogen supply. New Phytol. 2006, 171, 343-356. [CrossRef] [PubMed]

46. Munzi, S.; Cruz, C.; Branquinho, C.; Pinho, P.; Leith, I.D.; Sheppard, L.J. Can ammonia tolerance amongst lichen functional groups be explained by physiological responses? Environ. Pollut. 2014, 187, 206-209. [CrossRef] [PubMed]

47. Sundberg, B.; Ekblad, A.; Näsholm, T.; Palmqvist, K. Lichen respiration in relation to active time, temperature, nitrogen and ergosterol concentrations. Funct. Ecol. 1999, 13, 119-125. [CrossRef]

48. Munzi, S.; Pisani, T.; Loppi, S. The integrity of lichen cell membrane is a suitable parameter for monitoring early biological effects of nitrogen pollution. Ecotoxicol. Environ. Saf. 2009, 72, 2009-2012. [CrossRef]

49. Dahlman, L.; Zetherström, M.; Sundberg, B.; Näsholm, T.; Palmqvist, K. Measuring ergosterol and chitin in lichens. In Protocols in Lichenology - Culturing, Biochemistry, Physiology and Use in Biomonitoring; Kranner, I., Beckett, R., Varma, A., Eds.; Springer: Berlin/Heidelberg, Germany, 2002; pp. 348-362.

50. Johansson, O.; Olofsson, J.; Giesler, R.; Palmqvist, K. Lichen responses to nitrogen and phosphorus additions can be explained by the different symbiont responses. New Phytol. 2011, 191, 795-805. [CrossRef] [PubMed] 
51. Oksanen, I. Ecological and biotechnological aspects of lichens. Appl. Microbiol. Biotechnol. 2006, 73, 723-734. [CrossRef] [PubMed]

52. Molnár, K.; Farkas, E. Current results on biological activities of lichen secondary metabolites: A review. Z. Naturforsch. C 2010, 65, 157-173. [CrossRef]

53. Ström, C. Lichen Decline in Areas with Increased Nitrogen Deposition Might be Explained by Parasitic Fungi. A Survey of Parasitic Fungi on the Lichen Alectoria sarmentosa after 4 Years of Nitrogen Fertilization. Ph.D. Thesis, Umeå Universitat, Umeå, Sweden, 2011.

54. Welch, A.R.; Gillman, M.P.; John, E.A. Effect of nutrient application on growth rate and competitive ability of three foliose lichen species. Lichenologist 2006, 38, 177-186. [CrossRef]

55. Fałtynowicz, W. Reakcja runa boru suchego na jednorazowe nawożenie mineralne. Pr. IBL 1982, 582, 114-138.

56. Fałtynowicz, W. Zmiany biomasy runa boru chrobotkowego (Cladonio-Pinetum Juraszek 1928) pod wpływem nawożenia mineralnego. Doniesienia naukowe. Zesz. Nauk. WB i NZ UG 1983, 4, 109-121.

57. Vagts, I.; Kinder, M.; Müller, J. The effect of agrochemicals on the growth of Cladonia furcata. Lichenologist 1994, 26, 73-82. [CrossRef]

58. Vagts, I.; Kinder, M. The response of different Cladonia species after treatment with fertilizer or lime in heathland. Lichenologist 1999, 31, 75-83. [CrossRef]

59. Kytöviita, M.-M.; Crittenden, P.D. Growth and nitrogen relations in the mat-forming lichens Stereocaulon paschale and Cladonia stellaris. Ann. Bot. 2007, 100, 1537-1545. [CrossRef] [PubMed]

60. Pilkington, M.G.; Caporn, S.J.; Carroll, J.A.; Cresswell, N.; Lee, J.A.; Emmett, B.A.; Bagchi, T. Phosphorus supply influences heathland responses to atmospheric nitrogen deposition. Environ. Pollut. 2007, 148, 191-200. [CrossRef] [PubMed]

61. Hogan, E.J.; Minnullina, G.; Smith, R.I.; Crittenden, P.D. Effects of nitrogen enrichment on phosphatase activity and nitrogen: Phosphorus relationships in Cladonia portentosa. New Phytol. 2010, 186, 911-925. [CrossRef]

62. McCune, B. An unusual ammonia-affected lichen community on the Oregon Coast. Evansia 2003, 20, $132-137$.

63. Pinho, P.; Bergamini, A.; Carvalho, P.; Branquinho, C.; Stofer, S.; Scheidegger, C.; Máguas, C. Lichen functional groups as ecological indicators of the effects of land-use in Mediterranean ecosystems. Ecol. Indic. 2012, 15, 36-42. [CrossRef]

64. Giordani, P.; Matteucci, E.; Redana, M.; Ferrarese, A.; Isocrono, D. Unsustainable cattle load in alpine pastures alters the diversity and the composition of lichen functional groups for nitrogen requirement. Fungal Ecol. 2014, 9, 69-72. [CrossRef]

65. Aptroot, A.; van Herk, C.M. Lecanora barkmaneana, a new nitrophilous sorediate corticolous lichen from the Netherlands. Lichenologist 1999, 31, 3-8. [CrossRef]

66. Aptroot, A.; van Herk, C.M. Bacidia neosquamulosa, a new and rapidly spreading corticolous lichen species from western Europe. Lichenologist 1999, 31, 121-127. [CrossRef]

67. VDI. Biological measurement procedures for determining and evaluating the effects of ambient air pollutants by means of lichens (bioindication). Mapping the diversity of epiphytic lichens as an indicator of air quality. VDI 3957 2005, 13, 1-27.

68. Wirth, V. Ecological indicator values of lichens—Enlarged and updated species list. Herzogia 2010, 23, 229-248. [CrossRef]

69. Nimis, P.L. ITALIC - The Information System on Italian Lichens. Version 5.0. University of Trieste, Dept. of Biology. 2016. Available online: http://dryades.units.it/italic (accessed on 3 September 2020).

70. Giordani, P.; Brunialti, G.; Alleteo, D. Effects of atmospheric pollution on lichen biodiversity (LB) in a Mediterranean region (Liguria, northwest Italy). Environ. Pollut. 2002, 118, 53-64. [CrossRef]

71. Barkman, J.J. Phytosociology and Ecology of Cryptogamic Epiphytes; Van Gorcom and Comp. N.V.: Assen, The Netherlands, 1958.

72. Pinho, P.; Augusto, S.; Martins-Laução, M.A.; Pereira, M.J.; Soares, A.; Máguas, C.; Branquinho, C. Causes of change in nitrophytic and oligotrophic lichen species in Mediterranean climate: Impact of land cover and atmospheric pollutants. Environ. Pollut. 2008, 154, 380-389. [CrossRef] [PubMed]

73. Van Dobben, H.F.; Braak, C.J.F. Ranking of epiphytic lichen sensitivity to air pollution using survey data: A comparison of indicator scales. Lichenologist 1999, 31, 27-39. [CrossRef]

74. Loppi, S.; Bosi, A.; Signorini, C.; De Dominicis, V. Lichen recolonization of Tilia trees in Arezzo (Tuscany, central Italy) under conditions of decreasing air pollution. Cryptogam. Mycol. 2003, 24, 175-185. 
75. Stapper, N.J.; Franzen-Reuter, I. Mapping areal hypertrophication with epiphytic lichens as biomonitors in North-Rhine Westphalia (NRW, Germany). In Lichens in a Changing Pollution Environment; English Nature Research Report; Lambley, P., Wolseley, P., Eds.; English Nature: Worcester, UK, 2004; Volume 525, pp. 31-36.

76. Pinho, P.; Branquinho, C.; Cruz, C.; Tang, Y.S.; Dias, T.; Rosa, A.P.; Máguas, C.; Martins-Loução, M.-A.; Sutton, M.A. Assessment of critical levels of atmospheric ammonia for lichen diversity in cork-oak woodland, Portugal. In Atmospheric Ammonia; Sutton, M., Reis, S., Baker, S.M.H., Eds.; Springer Sciences+Business Media, B.V.: Dordrecht, The Netherlands, 2009; pp. 109-119.

77. Zarabska, D. Lichens in the Agricultural Landscape of Sandr Nowotomyski. Ph.D. Thesis, Adam Mickiewicz University, Poznań, Poland, 2011.

78. Rihm, B.; Urech, M.; Peter, K. Mapping ammonia emissions and concentrations for Switzerland-Effects on lichen vegetation. In Atmospheric Ammonia; Sutton, M., Reis, S., Baker, S.M.H., Eds.; Springer Sciences+Business Media, B.V.: Dordrecht, The Netherlands, 2009; pp. 87-92.

79. Asta, J.; Erhardt, W.; Ferretti, M.; Fornasier, F.; Kirschbau, U.; Nimis, P.L.; Purvis, O.W.; Pirintsos, S.; Scheidegger, C.; Van Haluwyn, C.; et al. European Guideline for Mapping Lichen Diversity as an Indicator of Environmental Stress. Br. Lichens. 2002, pp. 1-20. Available online: https://www.researchgate.net/ publication/303255153 (accessed on 23 November 2020).

80. Fenn, M.E.; Jovan, S.; Yuan, F.; Geiser, L.; Meixner, T.; Gimeno, B.S. Empirical and simulated critical loads for nitrogen deposition in California mixed conifer forests. Environ. Pollut. 2008, 155, 492-511. [CrossRef]

81. Giordani, P.; Calatayud, V.; Stofer, S.; Seidling, W.; Oliver, G.; Fischer, R. Detecting the nitrogen critical loads on European forests by means of epiphytic lichens. A signal-to-noise evaluation. Ecol. Manag. 2014, 311, $29-40$. [CrossRef]

82. Pinho, P.; Theobald, M.R.; Dias, T.; Tang, Y.S.; Cruz, C.; Martins-Louçăo, M.A.; Máguas, C.; Sutton, M.; Branquinho, C. Critical loads of nitrogen deposition and critical levels of atmospheric ammonia for semi-natural Mediterranean evergreen woodlands. Biogeosciences 2012, 9, 1205-1215. [CrossRef]

83. Geiser, L.H.; Jovan, S.E.; Glavich, D.A.; Porter, M.K. Lichen-based critical loads for atmospheric nitrogen deposition in Western Oregon and Washington Forests, USA. Environ. Pollut. 2010, 158, 2412-2421. [CrossRef]

84. Deduke, C.; Timsina, B.; Piercey-Normore, M.D. Effect of environmental change on secondary metabolite production in lichen-forming fungi. In International Perspectives on Global Environmental Change; Young, S.S., Silvern, S.E., Eds.; IntechOpen: London, UK, 2012; pp. 197-230.

Publisher's Note: MDPI stays neutral with regard to jurisdictional claims in published maps and institutional affiliations.

(C) 2020 by the author. Licensee MDPI, Basel, Switzerland. This article is an open access article distributed under the terms and conditions of the Creative Commons Attribution (CC BY) license (http://creativecommons.org/licenses/by/4.0/). 